\title{
ICT Investment Impact on Human Capital Development through the Channel of Financial Development in Bangladesh: An Investigation of Quantile ARDL and Toda-Yamamoto Test
}

\author{
Md. Qamruzzaman \\ Associate Professor, School of Business and Economics, \\ United International University, Dhaka, Bangladesh \\ Salma Karim \\ Professor, School of Business and Economics, \\ United International University, Dhaka, Bangladesh
}

DOI: https://doi.org/10.36941/ajis-2020-009o

Abstract

The study aims to assess the causal effects of ICT investment, financial development, and human capital development in Bangladesh for the period 1990-2019. To do so, we applied liner ARDL, Quantile ARDL, and directional causality investigated by performing a non-granger causality test. The result of Quantile ARDL confirms long-run effects running from ICT investment and financial development to human capital development. Considering the result short-run estimation, study findings established a positive association between financial development and human capital development but both positive and negative observed in ICT investment on human capital development. Furthermore, the nonlinear relationship established with the standard Wald test. Second, the results of directional causality test following Toda and Yamamoto (1995) proposed framework. Study findings established bidirectional causality running between financial development and human capital development and unidirectional causality running from ICT investment to human capital development. Therefore, it assumed that human capital development in Bangladesh critically relies on financial sector growth and development in the ICT sector. Furthermore, it is also observed that the bidirectional causal relationship also confirmed that is the development of either independent variables can influence each other.

Keywords: ICT investment; financial development; Human Capital Development; QARDL; Toda-Yamamoto; Bangladesh

\section{Introduction}

"Human resource development is a crucial requirement not only to build up technical knowledge and capabilities but also to create new values to help individuals and nations cope with rapidly changing social, environmental and development realities." - World Commission on Environment and Development(Imperatives, 1987)

Adam smith in 1977 postulated that "increasing division of labor may lead to economic prosperity". With the line with Adam smith, a growing number of researchers including Schultz (1961), Alexander 
(1997), Sen (1999a), Lazerson and Grubb (2004) come up with positive attitude by explaining the contribution of human capital in the process of economic growth, especially in the long-run. They postulated that human capital development intensifies the growth proposition through productivity enhancement and knowledge transfer. Human capital, according to Case and Fair (2007), is a set of interrelated macro factors including education, technical know-how, experience, and working habits that significantly influence the value of a marginal productivity working group.

Given that human capital is a pivotal element in the growth theory. It is because the acceleration of human capital with the investment in health, education, technological transformation eventually augment the speed of economic growth and support to achieve sustainable economic development (Barro, 20o1; Easterbrook, Kuppens, \& Manstead, 2016; Kottaridi, Louloudi, \& Karkalakos, 2019; Valencia Caicedo, 2019). It is implying that development in human capital creates ample avenue for inclusive economic growth with skilled manpower, resources optimization, and a balanced economy. However, Sen (1999b) postulated that the effects of ICT development contribute immensely in the process of transforming the population into human capital. The evolvement of ICT in the economy increases the possibility of getting benefits out of it including easy data processing, quick-time transactions, and diffusion of relevant information by overcoming the physical barriers. ICT adaption in the operational process assists the organization to increase productivity with timely decision making, effecting communication, and employee participation. Therefore, both the private and public sector prefers to implement technological development for enriching performance which eventually upgrades human skills in case of handling complex issues at large.

From a macro perspective, inclusive growth and development in one of the major outputs from the adaptation and implementation of ICT. The empirical literature suggests ICT evolvement increases the breadth of essential services in the economy including easy access to financial services like mobile banking, health care services, and online education at an affordable cost. and affordable (Bertot, Jaeger, \& Grimes, 2010; Naik, Joshi, \& Basavaraj, 2012). On top of that, ICT brings the population those are living in remote areas, into the mainstream of growth.

The motivation of the study to investigate the nexus between ICT investments, Human capital development through the interaction effect of financial development in Bangladesh during the period 1990-2019. Unleashing fresh evidence we applied linear ARDL proposed by M. Hashem Pesaran, Shin, and Smith (2001)and Quintile ARDL proposed by Cho, Kim, and Shin (2015). Besides, directional causality also investigated by following the granger non-causality test offer by Toda Toda and Yamamoto (1995). We observed from empirical estimation that in the long -run, both investment in ICT and financial development positively associated with Human capital development. However, a negative effect also established between ICT investment and human capital development in the short-run.

The remaining part of the study is structured as follows: Section 2 reviews the existing literature. The data and methodology are discussed in Section 3; Section 4 presents the empirical results and the implications; while Section 5 concludes the study

\section{Review of Literature}

In the empirical literature, we observed two lines of study findings focusing on human capital development. First, a growing number of researcher's concentrated on explaining the role of human capital on economic growth see for example (Jahfer \& FHA, 2016; Ranis, 2004; Ranis, Stewart, \& Ramirez, 2000; Son, 2010). Second, another group of researchers performed an empirical study for identifying the key determinants of human capital development with county-specific and panel data see for an instance (Abubakar, Kassim, \& Yusoff, 2015); Christopoulos and Tsionas (2004); (Shuaibu, 2016)(Neeliah \& Seetanah, 2016);(Thierry, Jun, Eric, Yannick, \& Landry, 2016); (DİNÇER \& YUKSEL, 2019); (KIRAN, YAVUZ, \& GÜRIŞ, 2009), KIRAN et al. (2009) Christopoulos and Tsionas (2004) 


\subsection{ICT and human capital development}

Human capital, according to (Barro, 2001; Jones, 2003), 2001) is relevant to achieve sustainable economic development. They postulated that human capital development not only augments the speed of growth but also ensure economic resources optimization, social security, and infrastructural development. Therefore, the role of macro determinants specifically ICT development emerged as the key concern for Human capital development (Jaiyeoba, 2015; S. Oluwatobi \& Ogunrinola, 2011; Uzodigwe, Umeghalu, \& Ozoh).

In a study of S. O. Oluwatobi, Olurinola, and Taiwo (2016), they examine the key determinants of human capital development in Sub-Saharan Africa for the periods 2001-2012 by performing system generalized method of moments (SGMM) technique. They established that the role of ICT development is decisive toward human capital development especially in the long-run. A group of researchers acclaimed that ICT evolvement is imperative for human capital development to see for an instance (Cheng, Mitomo, Otsuka, \& Jeon, 2015; Ilmakunnas \& Miyakoshi, 2013; Martin, Ciovica, \& Cristescu, 2013; Olubamise, 2010). According to Ahmed (2006), ICT investment at a firm-level increases total factor productivity due to an increase in employee productivity. He also advocates that ICT investment allows firms to enjoy skilled manpower that is efficient enough to handle the complex production process.

Furthermore, contradictory opinions also available in empirical literature. Ejemeyovwi, Osabuohien, and Osabohien (2018) performed an investigation of explaining the role of ICT investment in human capital development in ECOWAS for the 2004 to 2014 periods. Study findings suggest that investment in information and telecommunication development does not assist in human capital development in the long-run. , respectively.

All these studies validate the fact that a relationship exists between human CapitaLand ICT. However, no such study yet to investigated focusing on the nexus between ICT investment and human capital development in Bangladesh. With this study, therefore, we try to mitigate this research gap and explore fresh insights about how ICT development contributes to human capital development.

\subsection{Nexus between financial development and human capital development}

Human capital development, according to the empirical literature, the process also accelerates with the development of the financial sector. A growing number of empirical studies advocated a positive association between financial development and human capital development. For example, In a study, Hakeem and Oluitan (2012) investigated financial development and human capital development nexus with a time series approach in South Africa for the 1965-2005 periods. Study findings with granger-casualty test unveil feedback hypothesis by explaining bidirectional causal effects running between financial development and human capital development. Similar findings also available in De Gregorio (1992, 1996);Outreville (1999); Dwyfor Evans, Green, and Murinde (2002); Papagni (2006).

Furthermore, Kiliç and Ozcan (2018) performed an investigation for addressing the impact of financial development on human capital considering two sets of panel data for the 1990-2015 period in the emerging economy. Study findings revealed that in the long run financial development positively assists in human capital development. Furthermore, explaining directional causality between financial development and human capital development, Hatemi-J and Shamsuddin (2016) and Demirci and Özyakisir (2017) established unidirectional causality in their respective studies.

In another study performed by Wan (2014) for establishing the role of financial development and human capital accumulation on the socio-economic growth of china for the 1990-2011 periods. Several econometric tools were used namely unit root test, Johansen cointegration test, and directional causality established with granger causality test under VAR. study findings explain the long-run association between financial development, human capital development, and economic growth. Furthermore, the feedback hypothesis holds for explaining the effect of running from human 
capital development and economic growth.

In the study of Zaman, Izhar, Khan, and Ahmad (2012), they investigated nexus between financial development and human capital in Pakistan for the period 1975-2010. Study findings established the human capital development process significantly guided by financial development in the long-run, however, the indicator of market capitalization play an insignificant role in regards. Referring, variance decomposition results, it appears that the Money supply explains significant variance error in the short-run. Further evidence available in the study of Nik, Nasab, Salmani, and Shahriari (2013).

In a study by Hakeem and Oluitan (2012). They performed a causal investigation between financial development and human capital development in South Africa for the periods 1965-2005. Study findings unveiled unidirectional causality running from financial development to human capital development. Similar directional causality test performed by Sehrawat and Giri (2014b) in India for the periods 1980-2012. ARDL bound test confirmed the long-run association between financial development and human capital development. And the results of the granger causality test established unidirectional causality running from financial development to human capital development.

Further evidence observed in the study of Dwyfor Evans et al. (2002). They advocated that in the long-run, unidirectional causality running from financial development to human capital development. They conclude that a developed financial system is an essential complement to human capital development. Furthermore, financial development, according to Ukenna, Ijeoma, Anionwu, and Olise (2010), assists in skills development through augmentation of industrialization in the economy.

Another line of research findings also offered empirical litterateur. A group of researchers expressed their neutral attitudes in explaining the relationship between financial development and human capital development in different studies see, for an instance, Dwyfor Evans et al. (2002); Wan (2014).

\section{Data and Methodology}

\subsection{Variable definition}

The prime motivation of the study to investigate the nexus between ICT investment, financial development, and Human capital development in Bangladesh for the 1990-2019 period. All the variables are extracted from annual economic indicators reports published by the central bank of Bangladesh. All the variables are transformed into a natural $\log$ to overcome seasonal variation. Human capital development: following existing literature such as Ejemeyovwi et al. (2018); Shuaibu (2016), in this study, human capital development is measured by widely accepted prosy namely Human capital development index (HCDI). Financial development refers to the process of efficient financial intermediation, acceleration of economic resources mobilization, and access to financial service by large groups. In the empirical study, a number of proxy used by researchers for assessing financial development effects in the equation. However, a growing number of researches use " domestic credit to private section" as a proxy of financial development in their respective study see for an instance, Hatemi-J and Shamsuddin (2016); Sehrawat and Giri (2014a); Hakeem and Oluitan (2012). Investment in ICT measure by the proxy of investment in telecommunication by following Bankole, Osei-Bryson, and Brown (2013); Ejemeyovwi et al. (2018). Improvement in ICT assists in business development since the core elements like information accumulation, transformation, and reproduction for business purpose, intensify with the evolvement of ICT. Table 1 exhibits the data definition and descriptive statistics. 
Table 1: Varibale definition and Descriptive statistics

\begin{tabular}{|l|c|c|c|c|c|}
\hline Data & Identifier & Sources & Mean & Std. & Jarque-Bera \\
\hline Human development index & HC & WDI & 0.499 & 0.068 & 1.589 \\
\hline Investment in telecommunications & ICT & WDI & 5.450 & 1.509 & 9.147 \\
\hline Domestic credit to the private sector & FD & WDI & 3.322 & 0.393 & 2.303 \\
\hline
\end{tabular}

Source: Author compilation

\subsection{Autoregressive Distributed Lagged and Quantile ARDL}

To assess the nexus between investment in ICT, financial development, and human capital development, we perform two major econometric models namely linear autoregressive distributed lagged, hereafter ARDL propose by M. Hashem Pesaran et al. (2001).

The generalized ADRL model for assessing investment in ICT, financial development and human capital development in Bangladesh is as follows;

$$
H C_{t}=\alpha_{0}+\sum_{i=1}^{p} \mu_{1} H C_{t-i}+\sum_{i=0}^{q} \mu_{2} I C T_{t-i}+\sum_{i=0}^{y} \mu_{3} F D_{t-i}++\omega_{t}
$$

Where the coefficient of $\omega_{t}$ specify error correction term $\omega_{t}=H C_{t}-E\left[\frac{H C_{t}}{F_{t-1}}\right]$, with $F_{t-1}$ is the smallest $\sigma$ - field generated by........... and p, q, y lag order selected by Schwarz information criterion, respectively. In equation (1), HC, ICT, and FD represent Human capital development, Investment in Telecommunication, and Financial development, respectively.

We also consider dynamic Quantile Autoregressive Distributed Lag (QARDL) proposed by Cho et al. (2015) hereafter QARDL. Since QARDL is the combination of Autoregressive Distributed lagged (ARDL) of M. Hashem Pesaran et al. (2001), which enable to address both short-run and long-run relationship between dependent and independent variables and the Quantile regression method proposed by Koenker and Bassett Jr (1978) which captures the different state of the economy.

Extension of Eq. (1) to a Quantile context leads to the following form of the QARDL model:

$$
Q H C_{t}=\alpha_{0}(\tau)+\sum_{i=1}^{p} \mu_{1}(\tau) H C_{t-i}+\sum_{i=0}^{q} \mu_{2}(\tau) I C T_{t-i}+\sum_{i=0}^{y} \mu_{3}(\tau) F D_{t-i}+(\tau) \omega_{1 t}
$$

Where according to Kim and White (2003), $(\tau) \omega_{1 t}=H C_{t}-Q_{H C t}\left(\tau / \Omega_{t-1}\right)$, and $0<\tau<1$ is the Quantile.

To analysis QARDL, we reconstruct the equation (2) in the following manner:

$Q_{H C}=\alpha_{0}(\tau)+\sum_{i=1}^{p-1} \mu_{1}(\tau) \Delta H C_{t-i}+\beta_{1}(\tau) H C_{t}+\sum_{i=0}^{q-1} \mu_{2}(\tau) \Delta I C T_{t-i}+\beta_{2}(\tau) I C T_{t}+\sum_{i=0}^{y-1} \mu_{3}(\tau) \Delta F D_{t-i}+$ $\beta_{3}(\tau) F D_{t}+(\tau) \omega_{1 t} \quad(3)$

Where, $\beta_{H C}(\tau)=\sum_{i=0}^{p} \omega(\tau), \quad, \mu_{H C, t}(\tau)=-\sum_{j=i+0}^{p} \omega(\tau), \beta_{I C T}(\tau)=\sum_{i=0}^{p} \pi(\tau), \quad, \quad \mu_{I C T, t}(\tau)=$ $-\sum_{j=i+0}^{p} \pi(\tau), \beta_{F D}(\tau)=\sum_{i=0}^{p} \Upsilon(\tau)$, and, $\mu_{F D, t}(\tau)=-\sum_{j=i+0}^{p} \Upsilon(\tau)$,

The parameter in equation (3) only can capture short-run dynamics. To assess long-run effects running from financial development, ICT investment to human capital development, we reformulate equation (3) into the following equation (4):

\section{$Q_{H C}=\alpha(\tau)+X_{t}^{\prime} \beta(\tau)+M_{t}(\tau)$}

Where, $\mathrm{X}=[\mathrm{FD}, \mathrm{ICT}, \mathrm{HC}]$ and where, $\beta_{H C}(\tau)=\gamma_{H C}(\tau)\left[1-\sum_{i=1}^{p}\left[\mu_{H C}(\tau)\right] \rrbracket^{-1}\right.$ and $M_{t}(\tau)=$ $\sum_{j=0}^{\infty} \rho_{H C, j}(\tau) \Delta H C_{t-1}+\sum_{j=0}^{\infty} \theta_{H C, j}(\tau) \Delta \varepsilon_{t-1}$, with $\alpha(\tau)=\gamma(\tau)\left[1-\sum_{i=1}^{p} \mu(\tau)\right]^{-1}$ and $\alpha_{j}(\tau)=\sum_{l=j+1}^{\infty} \pi_{l} \tau$, $\beta_{F D}(\tau)$ and $\beta_{I C T}(\tau)$ will be computed similar way.

QARDL investigation subject of serial correlation, therefore to avoid serial correlation problem we reconstruct the equation into the following way:

$\begin{array}{ll}Q_{\Delta H C} & =\alpha+ \\ (\tau) \omega_{t} & (5)\end{array}$

Following Cho et al. (2015), the above equation (5) can be reparameterization into QARDL with an error correction term 
$Q_{\Delta H C}=\alpha(\tau)+\rho\left(H C_{t-1}-\beta_{i c t}(\tau) I C T_{t-1}-\beta_{f d}(\tau) F D_{t-1}\right)+\sum_{i=1}^{p-1} \mu_{i}(\tau) \Delta H C_{t-i}+\sum_{i=0}^{q-1} \beta_{2}(\tau) \Delta I C T_{t-i}+$ $\sum_{i=0}^{y-1} \Upsilon_{3}(\tau) \Delta F D_{t-i}+(\tau) \omega_{t}$

The cumulative short-term impact of the previous human capital developed on current human capital development is measured by $\mu_{*}=\sum_{j=1}^{p-1} \mu_{j}$ while the cumulative short-term impact of current and past levels of ICT investment, and financial development on current human capital development are measured by $\beta_{*}=\sum_{j=1}^{p-1} \beta_{j}$ and $\Upsilon_{*}=\sum_{j=1}^{p-1} \Upsilon_{j}$, respectively. The long-term cointegrating parameters for financial development and ICT investment are calculated as $\beta_{F D}=-\frac{\vartheta_{F D}}{\rho}$ and $\beta_{I C T}=-\frac{\vartheta_{I C T}}{\rho}$, respectively.

The cumulative short-term parameters and the long term cointegrating parameters are calculated using the delta method. It is worth noting that the ECM parameter $\rho$ should be significantly negative.

\subsection{Toda-Yamamoto causality test}

To assess directional causality between ICT investment, financial development, and Human capital Development. to do so, we follow the framework proposed by Toda and Yamamoto (1995), widely known as the Non-causality test. The assumption of exiting the granger causality test i.e., some parameters are jointly zero is not valid with integrated variables. Therefore, overcoming, the existing limitations in the traditional causality test, Toda and Yamamoto (1995) proposed a causality test utilizing the Modified WALD test for restriction on the parameters of a VAR $(k)$. The Toda and Yamamoto (1995) causality test based on the idea of Vector autoregressive at level $\left(P=K+D_{\max }\right)$ with correct VAR order $K$ and $d$ extra lag, where $d$ represents the maximum order of integration of time series.

Toda and Yamamoto's non-causality test, according to Zapata and Rambaldi (1997), possess certain advantages over the traditional Granger causality test. First, assessing causality with a noncausality test does not require cointegration properties in the system equation. Second, in case of mixed order of variables integration that is either I (o) and/or I (1) the MWALD test is capable to investigate existing causality between variables.

To apply the nexus between ICT investment, financial development, and Human capital development, we summarized the empirical model into the VAR system in the following equations, where each variable is treated as the dependent variable in respective equations.

$$
\begin{aligned}
& H C D_{t}=\alpha_{0}+\sum_{i=1}^{k} \beta_{1 i} H C D_{t-i}+\sum_{j=k+1}^{d_{\max }} \beta_{2 j} H C D_{t-j}+\sum_{i=1}^{k} \gamma_{1 i} I C T_{t-i}+\sum_{j=k+1}^{d_{\max }} \gamma_{1 j} I C T_{t-j}+ \\
& \sum_{i=1}^{k} \delta_{1 i} F D_{\text {vol }_{t-i}}+\sum_{j=k+1}^{d_{\text {max }}} \delta_{2 j} F D_{\text {vol }_{t-j}}+\varepsilon_{1 t} \\
& F D= \\
& \alpha_{0}+\sum_{i=1}^{k} \beta_{1 i} F D_{t-i}+\sum_{j=k+1}^{d_{\max }} \beta_{2 j} F D+\sum_{i=1}^{k} \gamma_{1 i} I C T_{t-i}+\sum_{j=k+1}^{d_{\max }} \gamma_{1 j} I C T_{t-j}+\sum_{i=1}^{k} \delta_{1 i} H C D_{v l_{t-i}}+ \\
& \sum_{j=k+1}^{d_{\max }} \delta_{2 j} H C D_{v_{\text {ol }} t-j}+\varepsilon_{1 t} \\
& I C T=\alpha_{0}+\sum_{i=1}^{k} \beta_{1 i} I C T_{t-i}+\sum_{j=k+1}^{d_{\max }} \beta_{2 j} I C T_{t-j}+\sum_{i=1}^{k} \gamma_{1 i} H C D_{t-i}+\sum_{j=k+1}^{d_{\max }} \gamma_{1 j} H C D_{t-j}+ \\
& \sum_{i=1}^{k} \delta_{1 i} F D_{v_{\text {ol }}-i}+\sum_{j=k+1}^{d_{\max }} \delta_{2 j} F D_{\text {vol }_{t-j}}+\varepsilon_{1 t}
\end{aligned}
$$

\section{Empirical Model and Interpretation}

Variables order of integration in the empirical test becomes significant due to econometric techniques selection guided by variables nature of integration. Therefore, establishing variable order of integration, in the study we performed unit root test by following Dickey and Fuller (1979) hereafter ADF test and Phillips and Perron (1988) hereafter P-P test with the null hypothesis of data is not stationary. Also, the unit root test proposes by Kwiatkowski, Phillips, Schmidt, and Shin (1992) hereafter KPSS test with the null hypothesis of data is stationary. The results of the unit root test 
exhibited in Table 2. According to test statistics with ADF and P-P test, we observed that variables exhibit non-stationary property at level but become stationary after the first difference. Similarly, the test statistics with the KPSS test, the null hypothesis of data is stationary is not rejected due to the insignificant estimation. In a nutshell, the variables are integrated after the first difference but there are no such variables in the study that are integrated after the second difference.

Table 2: Results of unit root tests

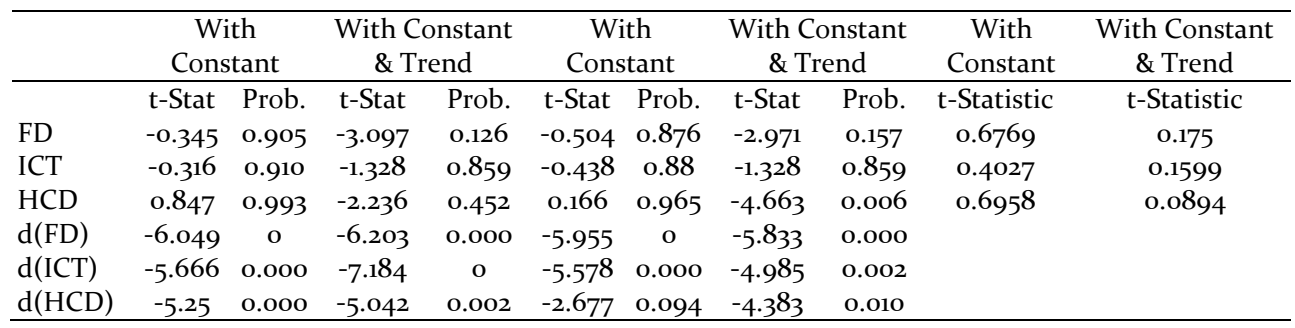

Sources: author calculation

Now we move to investigate their pairwise association by applying causality test as a preliminary assessment. The pairwise granger causality test result exhibited in Table 3 . We observed that bidirectional causality between ICT investment and financial development [ICT $\leftrightarrow \rightarrow F D$ ]. Study findings explaining that further financial development in the future will augment the nature of investment in the ICT sector by the government of Bangladesh, likewise, the growth in ICT investment will also make changes in the financial development process. Therefore, equitable development demands positive progress in both areas. Furthermore, unidirectional causality running from human capital development to ICT investment $[\mathrm{HCD} \rightarrow \mathrm{ICT}]$ and human capital development to finical development $[\mathrm{HCD} \rightarrow \mathrm{FD}]$.

Table 3: Results of linear Granger causality test

\begin{tabular}{lcccc}
\hline Null Hypothesis: & Obs & F-Statistic & Prob. & Causality direction \\
\hline FD $\neq \rightarrow$ ICT & 30 & 10.1139 & 0.0202 & FD $\leftarrow$ ICT \\
ICT $\neq \rightarrow$ FD & & 5.52195 & 0.00798 & \\
HCD $\neq \rightarrow$ ICT & 30 & 13.5819 & 0.0117 & HCD $\rightarrow$ ICT \\
ICT $\neq \rightarrow$ HCD & & 0.47364 & 0.8290 & \\
HCD $\neq \rightarrow$ FD & 30 & 12.03476 & 0.05241 & HCD $\rightarrow$ FD \\
FD $\neq \rightarrow$ HCD & & 0.46936 & 0.8316 & \\
\hline
\end{tabular}

Sources: author calculation

In the following section, we performed a test of cointegration following the procedure initiated by S. Johansen (1991); S Johansen (1995); S. Johansen (1998) for assessing whether the long-run association is available in the empirical model. The results of the cointegration test exhibited in Table 4. Study findings established a long-run association in the empirical equation by rejecting the null hypothesis of at most 1 cointegration at a $5 \%$ level of significance. It is implying that in the long-run investment in ICT, financial development, and human capital development move together. 
Table 4: Johansen Cointegration Tests of the Bivariate Models

\begin{tabular}{lcccc}
\hline Hypothesized No. of CE(s) & Eigenvalue & $\begin{array}{c}\text { Trace } \\
\text { Statistic }\end{array}$ & $\begin{array}{c}\text { 0.05 } \\
\text { Critical Value }\end{array}$ & Prob. $^{* *}$ \\
\hline None * & 0.920098 & 90.30720 & 29.79707 & 0.0000 \\
At most 1 * & 0.744864 & 32.18721 & 15.49471 & 0.0001 \\
At most 2 & 0.032932 & 0.770195 & 3.841466 & 0.3802 \\
Trace test indicates 2 cointegrating equations(s) at the 0.05 level & & \\
* denotes rejection of the hypothesis at the o.05 level & & & \\
**MacKinnon-Haug-Michelis (1999) p-values & & & \\
\hline
\end{tabular}

Source: Author's calculation

\subsection{Autoregressive Distributed Lagged and Quantile ARDL estimation}

The next section dealing with empirical model estimation by applying autoregressive distributed lagged hereafter ARDL propose by M Hashem Pesaran and Smith (1995) and further development initiated by M. Hashem Pesaran et al. (2001). The result of linear ARDL exhibited in Table 5 (PanelA). besides linear ARDL, in the study, we also perfumed Quintile ARDL by following the framework proposed by Cho et al. (2015) and the results of Quintile ARDL exhibited in Panel-B.

Considering linear ARDL results. It is obvious, in the long-run, a positive association established between investment in ICT (a coefficient of 0.051) and financial development (0.103) with human capital development in Bangladesh and all the coefficients are statistically significant at a $1 \%$ level of significance. More specifically, a 10\% increase in ICT investment results for a $5.1 \%$ development in human capital. It is implying that further development in information and telecommunication will boost the process of human capital accumulation in the economy. Furthermore, a $10 \%$ improvement in financial development results in a $10.3 \%$ enhancement in human capital development. In a nutshell, in the long-run, both variables namely IC T investment and financial development positively support the process of human capital accumulation.

For short-run, the coefficient of error correction (a coefficient of -0.405) is negative and statistically significant. Finding suggesting that there is long-run convergence with a speed of $40.5 \%$, having short-run shock in the model. Considering the magnitude of ICT (a coefficient of -0.002) is negative and financial development (a coefficient of o.0902) is positively linked with the human capital accumulation process but only the coefficient of financial development is statistically significant at a $5 \%$ level of significance.

Referring to the results of Quantile ARDL model estimation, we perform o.10 Quantile to o.8o Quantile of addressing magnetite of investment in ICT and financial development on human capital development in Bangladesh both in the long-run and short -run. The ECM parameter ( ) measures the speed of adjustment towards the long-run equilibrium at quantile . Considering the coefficients of the error correction term is statistically significant at a $1 \%$ or $5 \%$ level of significance with the expected sign i.e., negative. These findings indicating that three is the reversion relationship between ICT investment, financial development, and Human capital development in Bangladesh.

In the long run, it is obvious that there is a positive association between investment in ICT and human capital development with the given Quantile, the coefficients range from 0.094 to 0.253 . It is evident from the results that with the higher quantile the coefficient $\beta_{I C T}$ is significant. It is noteworthy to address that over the period investment in the ICT sector emerges as a catalyst in the process of human capital. Therefore, future endeavors in accelerating the ICT sector development through both public and private investment can contribute more. Moreover, the development of the ICT sector in the economy could boost economic integration by allowing easy access to information.

The empirical finding also suggests that the coefficient of $\beta_{F D}$ is higher and statistically significant at the higher quantile. However, the negative effects also manifested at lower quantile that is $q=335$. 
Table 5: Results of linear ARDL and Quintile ARDL

\begin{tabular}{|c|c|c|c|c|c|c|}
\hline & $\beta_{I C T}$ & $\beta_{F D}$ & $\mu$ & $\beta$ & $r$ & $\rho$ \\
\hline ARDL & 0.05171 & 0.103 & 0.081008 & -0.0024 & 0.09024 & -0.404 \\
\hline 0.10 & $\begin{array}{c}0.0247 \\
(0.0505)\end{array}$ & $\begin{array}{c}0.0515 \\
(0.0002)\end{array}$ & $\begin{array}{l}0.0690 \\
\text { (o.000) }\end{array}$ & $\begin{array}{c}-0.0014 \\
(0.0002)\end{array}$ & $\begin{array}{c}0.0127 \\
(0.000)\end{array}$ & $\begin{array}{c}-0.053 \\
(0.000)\end{array}$ \\
\hline 0.20 & $\begin{array}{c}0.098 \\
(0.009)\end{array}$ & $\begin{array}{c}0.0224 \\
(0.000)\end{array}$ & $\begin{array}{c}0.09759 \\
(0.000)\end{array}$ & $\begin{array}{l}-0.0352 \\
(0.0001)\end{array}$ & $\begin{array}{c}0.08492 \\
(0.000)\end{array}$ & $\begin{array}{c}-0.007 \\
\text { (o.00o) }\end{array}$ \\
\hline 0.30 & $\begin{array}{c}0.0947 \\
(0.0505) \\
\end{array}$ & $\begin{array}{c}0.02515 \\
(0.0002) \\
\end{array}$ & $\begin{array}{c}0.09690 \\
(0.000)\end{array}$ & $\begin{array}{c}-0.0034 \\
(0.0002) \\
\end{array}$ & $\begin{array}{l}0.09127 \\
(0.000) \\
\end{array}$ & $\begin{array}{c}-0.053 \\
(0.000) \\
\end{array}$ \\
\hline 0.30 & $\begin{array}{c}0.0947 \\
(0.0505)\end{array}$ & $\begin{array}{c}0.02515 \\
(0.0002)\end{array}$ & $\begin{array}{c}0.09690 \\
(0.000)\end{array}$ & $\begin{array}{c}-0.0034 \\
(0.0002)\end{array}$ & $\begin{array}{l}0.09127 \\
(0.000)\end{array}$ & $\begin{array}{c}-0.153 \\
(0.000)\end{array}$ \\
\hline 0.4 & $\begin{array}{c}0.1247 \\
(0.0091)\end{array}$ & $\begin{array}{l}0.03168 \\
(0.000)\end{array}$ & $\begin{array}{c}0.09699 \\
(0.000)\end{array}$ & $\begin{array}{l}-0.0371 \\
(0.000)\end{array}$ & $\begin{array}{c}0.09299 \\
(0.000)\end{array}$ & $\begin{array}{c}-0.163 \\
(0.000)\end{array}$ \\
\hline 0.5 & $\begin{array}{c}0.1498 \\
(0.009)\end{array}$ & $\begin{array}{c}0.03224 \\
(0.000)\end{array}$ & $\begin{array}{c}0.09759 \\
(0.000)\end{array}$ & $\begin{array}{l}-0.0352 \\
(0.0001)\end{array}$ & $\begin{array}{c}0.08492 \\
(0.000)\end{array}$ & $\begin{array}{c}-0.107 \\
(0.000)\end{array}$ \\
\hline 0.6 & $\begin{array}{c}0.209 \\
(0.0292)\end{array}$ & $\begin{array}{c}0.0381 \\
(0.0001)\end{array}$ & $\begin{array}{c}0.09739 \\
(0.000)\end{array}$ & $\begin{array}{c}-0.0344 \\
(0.000)\end{array}$ & $\begin{array}{l}0.0906 \\
(0.000)\end{array}$ & $\begin{array}{c}-0.612 \\
(0.000)\end{array}$ \\
\hline 0.7 & $\begin{array}{c}0.253 \\
(0.087) \\
\end{array}$ & $\begin{array}{l}0.0399 \\
(0.000)\end{array}$ & $\begin{array}{l}0.0990 \\
(0.000)\end{array}$ & $\begin{array}{c}-0.0317 \\
(0.0001)\end{array}$ & $\begin{array}{c}0.0776 \\
(0.0021)\end{array}$ & $\begin{array}{c}-0.050 \\
(0.000)\end{array}$ \\
\hline 0.8 & $\begin{array}{c}0.231 \\
(0.0109)\end{array}$ & $\begin{array}{c}0.0525 \\
(0.0002)\end{array}$ & $\begin{array}{c}0.09998 \\
(0.000)\end{array}$ & $\begin{array}{l}-0.0028 \\
(0.0001)\end{array}$ & $\begin{array}{l}0.0869 \\
(0.000)\end{array}$ & $\begin{array}{c}-0.090 \\
(0.000)\end{array}$ \\
\hline
\end{tabular}

Note: the value in the () indicates associate p-value.

Source: Author calculation

The asymmetric effects of ICT investment and financial development on human capital development confirmed by the results of the Wald test, which is exhibited in Table 6. In particular, the results of the Wald test reject the null of parameter consistency for the speed of adjustment parameter and the long-run parameter. Thus confirmed the existence of a nonlinear relationship between ICT investment, financial development, and Human capital development. Furthermore, considering the short-run effects, Wald test results confirmed the presence of asymmetric effects running from ICT investment and financial development.

Table 6: Wald test results

\begin{tabular}{|c|c|c|c|c|c|c|}
\hline & $\beta_{I C T}$ & $\beta_{F D}$ & $\mu$ & $\beta$ & $\Upsilon$ & $\rho$ \\
\hline Wald-stat & $14.478^{\star * *}$ & $11.425^{* * *}$ & $9.751^{* *}$ & $8.224^{* *}$ & $4.778^{* * *}$ & $17.241^{* *}$ \\
\hline
\end{tabular}

\subsection{Granger causality test following Toda-Yamamoto}

This section dealing with the investigation of the directional causality test by empirical equation (68 ) by following the non-causality test propose by Toda-Yamamoto. The results of the non-granger causality test exhibited in Table 6 . The optimal lag length $(k)$ for each of the variables by using Akaike information criteria is 2. Besides, the Toda and Yamamoto test are estimated using VAR at the level of order $p=k+d$ max.

Considering the result of the causality test, we observe that the "feedback hypothesis" holds in explaining the causal relationship between financial development and human capital development $[\mathrm{HCD} \leftarrow \rightarrow \mathrm{FD}]$ and investment in ICT and financial development [ICT $\leftarrow \rightarrow F D]$. Study findings suggesting that any future development in either variable, the expected consequence to be observed in other variables. Policy formulation, therefore, the process needs to be more attentive and careful 
so that aggregate effects can be maximized shortly. Furthermore, unidirectional causality disclosed between investments in ICT to human capital development [ICT $\rightarrow$ HCD].

Table 7: Toda and Yamamoto Approach of Granger Causality Test Results

\begin{tabular}{|l|c|c|c|}
\hline \multirow{2}{*}{ Dependent variable } & \multicolumn{3}{|c|}{ Independent variables } \\
\cline { 2 - 4 } & HCD & ICT & FD \\
\hline HCD & - & $14.923^{* * *}$ & $24.562^{* * *}$ \\
\hline ICT & 7.728 & - & $16.344^{* *}$ \\
\hline FD & $13.656^{* * *}$ & $13.603^{* * *}$ & - \\
\hline
\end{tabular}

Note: ${ }^{* * *}$ indicates statistically significant at a $1 \%$ level.

\section{Findings and Discussion}

Digitalization is one of the prime motivations by the ruling government since 1990. Increment of aggregate production, human capital development, reduction of transaction costs is the price outcome with ICT development in Bangladesh, which is observed over periods. In line with the ICT investment trend, the motivation of the study is to explore fresh evidence regarding the role of ICT investment in human capital development through the interaction of financial development for the periods 1990-2017. Investigating the nexus between ICT investment, financial development, and human capital development, we applied liner ARDL proposed by M. Hashem Pesaran et al. (2001)and quantile ARDL proposed by Cho et al. (2015). Furthermore, the directional relationship was investigated by following the non-granger causality test propose by Toad Toda and Yamamoto (1995). The key summary findings are exhibited below:

First, the empirical model estimation with quantile ARDL established a positive association between ICT investment, financial development, and human capital development, especially in the long-run. Referring to the short-run model estimation, we observed a mixed effect running from ICT investment to human capital development that is positive and negative. However, the effects of financial development on human capital are aligned with the long-run effect, which implies a positive association. Our study findings are supported by empirical studies see, for an instance Khan, Hussain, Shahbaz, Yang, and Jiao (2020) Oyinlola and Adedeji (2019) Wan (2014) Gillman and Kejak (2007). Furthermore, the results of the standard Wald test confirmed the nonlinear relationship between ICT investment, financial development, and human capital development in Bangladesh.

Second, the results of directional causality test following Toda and Yamamoto (1995) proposed framework. Study findings established bidirectional causality running between financial development and human capital development and unidirectional causality running from ICT investment to human capital development. Therefore, it assumed that human capital development in Bangladesh critically relies on financial sector growth and development in the ICT sector. Furthermore, it is also observed that the bidirectional causal relationship also confirmed that is the development of either independent variables can influence each other.

\section{Conclusion and Policy Implication}

It is obvious from the study findings that both investments in ICT and financial development are critically important for human capital development in Bangladesh. Furthermore, the joint effects of ICT and financial development also positively associated with the process of human capital development, especially in the long-run.

The results of this study will prove to be useful for ICT and human capital policy formulation. In this context, a comparison of the contributions of ICT and human capital to productivity growth in the Bangladeshi economy provides a guideline for the policymakers to formulate appropriate national and international ICT and human capital policies. 
Furthermore, study findings appropriately direct in policy formulation pertinent to mitigating the skills manpower scarcity through human capital development in the economy for sustainable economic growth in Bangladesh. Therefore, effective ICT program implementation and inclusive access to financial services are the key determinants for human capital development, especially in the long-run. Financial inclusion not only boosts the economic process but also play a catalyst role in accelerating the speed of human capital development by offering growth propensity. ICT adaption and availability with access to financial services allow the transformation of the population to manpower since ICT literature and access to credit.

Based on empirical finds some policy implications. First, the governments of Bangladesh should consider the financial development level and investment in the ICT sector while making projections for the future national human capital demand. Otherwise, further developments in human capital in a way that has not been accounted for, resulting in more difficulties for achieving their planned human development targets. Second, the policies of economic development, finance, and ICT education should be simultaneously considered as there are strong bilateral relations among the corners of the development-finance and human capital triangle. Financial policies targeting more investment in ICT education (e.g. lowering interest rates for educational loans) will likely create more ICT adopted people with high financial literacy rates. Educated people will likely support the development of the financial sector as they have sufficient acquaintance with financial instruments

As a final note, future studies can expand the scope in several ways. First, a financial index can be constructed based on different proxies for financial development, such as capital market-based indicators. Likewise, different proxies for human capital or human development, such as HDI, could be used. Moreover, the existing literature is still in its infancy and needs further studies to analyze the issue for different countries.

\section{Acknowledgment}

We would like to express our heartfelt thanks and gratitude to an anonymous reviewer for his/her constructive suggestions. We would also thank Marco Cilento, editor-in-Chief of this journal for his consideration in publishing the article. The study received a research grant from The Institute of Advanced Research (IAR), United International University (Grant Reference: UIU/IAR/o2/2019-20/BE/o1)

\section{References}

Abubakar, A., Kassim, S. H., \& Yusoff, M. B. (2015). Financial development, human capital accumulation and economic growth: empirical evidence from the Economic Community of West African States (ECOWAS). Procedia-social and behavioral sciences, 172, 96-103.

Ahmed, E. M. (2006). ICT and human capital role in achieving knowledge-based economy: applications on Malaysia's manufacturing. Journal of Information \& Knowledge Management, 5(02), 117-128.

Alexander, W. R. J. (1997). Inflation and economic growth: evidence from a growth equation. Applied Economics, 29(2), 233-238. doi:10.1080/000368497327290

Bankole, F. O., Osei-Bryson, K.-M., \& Brown, I. (2013). The impact of ICT investments on human development: a regression splines analysis. Journal of Global Information Technology Management, 16(2), 59-85.

Barro, R. J. (2001). Human capital and growth. American Economic Review, 91(2), 12-17.

Bertot, J. C., Jaeger, P. T., \& Grimes, J. M. (2010). Using ICTs to create a culture of transparency: E-government and social media as openness and anti-corruption tools for societies. Government information quarterly, 27(3), 264-271.

Case, K. E., \& Fair, R. C. (2007). Principles of microeconomics: Pearson Education.

Cheng, J. W., Mitomo, H., Otsuka, T., \& Jeon, S. Y. (2015). The effects of ICT and mass media in post-disaster recovery-a two model case study of the Great East Japan Earthquake. Telecommunications Policy, 39(6), 515-532.

Cho, J. S., Kim, T.-h., \& Shin, Y. (2015). Quantile cointegration in the autoregressive distributed-lag modeling framework. Journal of Econometrics, 188(1), 281-300.

Christopoulos, D. K., \& Tsionas, E. G. (2004). Convergence and regional productivity differences: Evidence from Greek prefectures. The Annals of Regional Science, 38(3), 387-396. 
De Gregorio, J. (1992). Economic growth in latin america. Journal of Development Economics, 39(1), $59-84$.

De Gregorio, J. (1996). Borrowing constraints, human capital accumulation, and growth. Journal of Monetary Economics, 37(1), 49-71.

Demirci, N. S., \& Özyakisir, D. (2017). Finansal Gelismislik ve Beseri Sermaye Arasindaki Iliski: Türkiye için Zaman Serileri Analizi (1971-2013)/The Relationship Between Financial Development and Human Capital: Time Series Analysis for Turkey (1971-2013). Finans Politik E Ekonomik Yorumlar, 54(624), 25.

Dickey, D. A., \& Fuller, W. A. (1979). Distribution of the Estimators for Autoregressive Time Series with a Unit Root. Journal of the American Statistical Association, 74(366a), 427-431. doi:10.1080/01621459.1979.10482531

Dinçer, H., \& Yuksel, S. (2019). Identifying the causality relationship between health expenditure and economic growth: an application on E7 countries. Journal of Health Systems and Policies, 1(1), 5-23.

Dwyfor Evans, A., Green, C. J., \& Murinde, V. (2002). Human capital and financial development in economic growth: new evidence using the translog production function. International Journal of Finance E Economics, $7(2), 123-140$.

Easterbrook, M. J., Kuppens, T., \& Manstead, A. S. (2016). The education effect: Higher educational qualifications are robustly associated with beneficial personal and socio-political outcomes. Social Indicators Research, 126(3), 1261-1298.

Ejemeyovwi, J. O., Osabuohien, E., \& Osabohien, R. (2018). ICT investments, human capital development and institutions in ECOWAS. International Journal of Economics and Business Research, 15(4), 463-474.

Gillman, M., \& Kejak, M. (2007). Inflation, Financial Development, and HumanCapital-Based Endogenous Growth: an Explanation of Ten Empirical Findings. Paper presented at the Centre for dynamic macroeconomic analysis, Conference Papers.

Hakeem, M., \& Oluitan, O. (2012). Financial development and human capital in South Africa: a time-series approach. Research in Applied Economics, 4(3), 18.

Hatemi-J, A., \& Shamsuddin, M. (2016). The causal interaction between financial development and human development in Bangladesh. Applied Economics Letters, 23(14), 995-998.

Ilmakunnas, P., \& Miyakoshi, T. (2013). What are the drivers of TFP in the Aging Economy? Aging labor and ICT capital. Journal of Comparative Economics, 41(1), 201-211.

Imperatives, S. (1987). Report of the World Commission on Environment and Development: Our common future. Accessed Feb, 10.

Jahfer, A., \& FHA, R. (2016). The relationship between financial development, human capital development and economic growth in Sri Lanka.

Jaiyeoba, S. V. (2015). Human capital investment and economic growth in Nigeria. African Research Review, 9(1), 30-46.

Johansen, S. (1991). Estimation and Hypothesis Testing of Cointegration Vectors in Gaussian Vector Autoregressive Models. Econometrica, 59, 1551-1580.

Johansen, S. (1995). Likelihood-Based Inference in Cointegrated Vector Autoregressive Models. Oxford: Oxford University Press.

Johansen, S. (1998). Statistical analysis of co integration vectors. Journal of Economic Dynamics and Control, 1o(4), 231-254.

Jones, C. I. (2003). Human capital, ideas and economic growth. In Finance, Research, Education and Growth (pp. 51-74): Springer.

Khan, Z., Hussain, M., Shahbaz, M., Yang, S., \& Jiao, Z. (2020). Natural resource abundance, technological innovation, and human capital nexus with financial development: a case study of China. Resources Policy, 65, 101585.

Kiliç, C., \& Ozcan, B. (2018). The Impact of Financial Development on Human Capital: Evidence From Emerging Market Economies. International Journal of Economics and Financial Issues, 8(1), 258.

Kim, T.-H., \& White, H. (2003). Estimation, inference, and specification testing for possibly misspecified quantile regression. Advances in Econometrics, 17, 107-132.

Kiran, B., Yavuz, N. Ç., \& Güriş, B. (2009). Financial Development and Economic Growth: Time Series Evidence from Turkey.

Koenker, R., \& Bassett Jr, G. (1978). Regression quantiles. Econometrica: Journal of the Econometric Society, 33-50.

Kottaridi, C., Louloudi, K., \& Karkalakos, S. (2019). Human capital, skills and competencies: Varying effects on inward FDI in the EU context. International Business Review, 28(2), 375-390.

Kwiatkowski, D., Phillips, P., Schmidt, P., \& Shin, Y. (1992). Testing the null hypothesis of stationarity against the alternative of a unit root: How sure are we that economic time series have a unit root? Journal of Econometrics, 54(1-3), 159-178.

Lazerson, M., \& Grubb, W. N. (2004). The education gospel: The economic power of schooling: Harvard University Press. 
Martin, F. M., Ciovica, L., \& Cristescu, M. P. (2013). Implication of Human Capital in the Development of SMEs through the ICT Adoption. Procedia Economics and Finance, 6, 748-753.

Naik, G., Joshi, S., \& Basavaraj, K. (2012). Fostering inclusive growth through e-governance embedded rural telecenters (EGERT) in India. Government information quarterly, 29, S82-S89.

Neeliah, H., \& Seetanah, B. (2016). Does human capital contribute to economic growth in Mauritius? European Journal of Training and Development, 40(4), 248-261.

Nik, H., Nasab, Z., Salmani, Y., \& Shahriari, N. (2013). The relationship between financial development indicators and human capital in Iran. Management Science Letters, 3(4), 1261-1272.

Olubamise, B. O. (2010). ICT and Human Capital Development: A Critical Factor for National Development. Available at SSRN 1604432.

Oluwatobi, S., \& Ogunrinola, I. O. (2011). Government expenditure on human capital development: Implications for economic growth in Nigeria. Journal of Sustainable Development, 4(3).

Oluwatobi, S. O., Olurinola, I. O., \& Taiwo, O. (2016). Human capital development in Sub-Saharan Africa: The role of ICT. Journal of Economics Studies and Research, 2016, d1-11.

Outreville, J. F. (1999). Financial development, human capital and political stability.

Oyinlola, M. A., \& Adedeji, A. (2019). Human capital, financial sector development and inclusive growth in subSaharan Africa. Economic Change and Restructuring, 52(1), 43-66.

Papagni, E. (2006). Household borrowing constraints, fertility dynamics, and economic growth. Journal of Economic Dynamics and Control, 30(1), 27-54.

Pesaran, M. H., Shin, Y., \& Smith, R. J. (2001). Bounds testing approaches to the analysis of level relationships. Journal of Applied Econometrics, 16(3), 289-326. doi:10.1002/jae.616

Pesaran, M. H., \& Smith, R. (1995). Estimating long-run relationships from dynamic heterogeneous panels. Journal of Econometrics, 68(1), 79-113.

Phillips, P. C. B., \& Perron, P. (1988). Testing for a unit root in time series regression. Biometrika, 75(2), $335-346$. doi: https://doi.org/10.1093/biomet/75.2.335

Ranis, G. (2004). Human development and economic growth. Yale University Economic Growth Center Discussion Paper(887).

Ranis, G., Stewart, F., \& Ramirez, A. (200o). Economic growth and human development. World Development, 28(2), 197-219.

Schultz, T. W. (1961). Investment in Human Capital. The American Economic Review, 51(1), 1-17.

Sehrawat, M., \& Giri, A. (2014a). The relationship between financial development indicators and human development in India. International Journal of Social Economics, 41(12), 1194-1208.

Sehrawat, M., \& Giri, A. (2014b). The relationship between financial development indicators and human development in India. International Journal of Social Economics.

Sen, A. (1999a). Development as Freedom (New York: Anchor). South Indian ICT Clusters, 227.

Sen, A. (1999b). Development as Freedom Oxford University Press. New Delhi.

Shuaibu, M. (2016). Determinants of human capital development in Africa: a panel data analysis. Oeconomia Copernicana, $7(4), 523-549$.

Son, H. H. (2010). Human capital development. Asian Development Bank Economics Working Paper Series(225).

Thierry, B., Jun, Z., Eric, D. D., Yannick, G. Z. S., \& Landry, K. Y. S. (2016). Causality relationship between bank credit and economic growth: Evidence from a time series analysis on a vector error correction model in Cameroon. Procedia-social and behavioral sciences, 235, 664-671.

Toda, H. Y., \& Yamamoto, T. (1995). Statistical inference in vector autoregressions with possibly integrated processes. Journal of Econometrics, 66(1-2), 225-250.

Ukenna, S., Ijeoma, N., Anionwu, C., \& Olise, M. C. (2010). Effect of investment in human capital development on organisational performance: empirical examination of the perception of small business owners in Nigeria. European Journal of Economics, Finance and Administrative Sciences, 93-107.

Uzodigwe, A. A., Umeghalu, C. C., \& Ozoh, J. N. Human Capital Development and Economic Growth In Nigeria.

Valencia Caicedo, F. (2019). The mission: Human capital transmission, economic persistence, and culture in South America. The Quarterly Journal of Economics, 134(1), 507-556.

Wan, G. (2014). Financial development, human capital and economic growth. Asian Agricultural Research, 6(18122016-144244), 39-43.

Zaman, K., Izhar, Z., Khan, M. M., \& Ahmad, M. (2012). Retracted: The relationship between financial indicators and human development in Pakistan. Economic Modelling, 29(5), $1515-1523$. doi:http://dx.doi.org/10.1016/j.econmod.2012.05.013

Zapata, H. O., \& Rambaldi, A. N. (1997). Monte Carlo evidence on cointegration and causation. Oxford Bulletin of Economics and Statistics, 59(2), 285-298. 